|Araştırma Makalesi / Research Article|

\title{
Yetişkinliğe Geçişte illk Adım: Gelişimsel Yetersizliği Olan Bireyler ve Kariyer Eğitimi
}

\section{First Step to Transition: Individuals with Developmental Disabilities and Career Education}

\section{Tahir Mete Artar ${ }^{1}$, Yasemin Ergenekon ${ }^{2}$}

Anahtar Kelimeler
gelişimsel yetersizliği
olan yetişkinler
yetişkinliğe geçiş
bağımsız yaşam
kariyer eğitimi
özel eğitim

\section{Keywords}

adults with

developmental

disabilities

transition to adulthood

independent living

career education

special education

Başvuru Tarihi/Received

09.08.2019

Kabul Tarihi /Accepted

04.09.2020

\section{Öz}

Bu çalışmanın amacı, gelişimsel yetersizliği olan bireylerin yetişkinlik yaşamının önemli bir parçası olan kariyer, kariyer gelişimi ve kariyer eğitimi kavramlarının açıklanması ve erken çocukluk döneminden itibaren gelişimsel yetersizliği olan bireylerin başarılı bir yetişkinlik yaşamı sürdürebilmesi için gerçekleştirilebilecek uygulamaları içeren önerilerin geliştirilmesidir. Çalışmada öncelikle gelişimsel yetersizliği olan bireyler ve onların yetişkinliğe geçiş süreci ortaya konmuş, ardından başarılı bir yetişkinlik yaşamı için kritik beceri alanlarının neler olduğu paylaşıımıştır. Sonrasında bağımsız bir yetişkinlik yaşamıyla gelişimsel yetersizliği olan bireylerin çalışma yaşamına katılımının ilişkisi açıklanmış ve çalışma yaşamına sürdürülebilir şekilde katııımda kariyer gelişimi kavramının önemini içeren alanyazındaki çalışma bulguları paylaşılmıştır. Bununla birlikte, gelişimsel yetersizliği olan bireylerin eğitiminde okul döneminden itibaren gerçekleştirilebilecek kariyer eğitimi çalışmaları örnekleriyle birlikte açıklanmıştır. Son olarak gelişimsel yetersizliği olan bireylerin kariyer gelişimlerinin desteklenmesi için paydaşlara öneriler sunulmuştur.

\section{Abstract}

The purpose of the present study was to describe career, career development and career training concepts which are an important part of adulthood lives of individuals with developmental disabilities and to propose some suggestions of implementations starting from early childhood years for a successful adulthood for individuals with developmental disabilities. First of all, individuals with developmental disabilities and their transition procedure to adulthood were tried to be presented, and then, critical skill areas for a successful adulthood life were shared. Afterwards, the research studies examining the relationship between an independent adulthood lives and taking part in the working life continuously for individuals with developmental disabilities were discussed. Besides, career education studies to be conducted starting from the school years of an individual with developmental disability were described by providing examples. Lastly, some suggestions were presented to the stakeholders for supporting the career development of individuals with developmental disabilities.

\footnotetext{
${ }^{1}$ Anadolu Üniversitesi, Eğitim Fakültesi, Özel Eğitim Bölümü, Eskişehir, Türkiye, https://orcid.org/0000-0002-0285-4152 ${ }^{2}$ Anadolu Üniversitesi, Eğitim Fakültesi, Özel Eğitim Bölümü, Eskişehir, Türkiye, https://orcid.org/0000-0003-2443-0884
}

Alıntı/Citation: Artar, T. M., \& Ergenekon, Y. (2020). Yetişkinliğe geçişte ilk adım: Gelişimsel yetersizliği olan bireyler ve kariyer eğitimi. Kastamonu Education Journal, 28(5), 1902-1914. doi: 10.24106/kefdergi.3892 


\section{Extended Abstract}

\section{Introduction}

Transition can be described as, a person's movement process from being a student to being an adult living in the community. The roles of a person who is an adult in the community living are; to work in a job, continuing home living independently, taking part in the community living, and developing social relationships. Individuals with developmental disabilities who are during their transition process to adulthood wish to work in a job and continue this job by establishing social relationships (Cooney, 2002; Cooney, Jahoda, Gumley and Knott, 2006). Due to this reason, transition plans containing planing and preparation for adulthood for individuals with developmental disabilities has an important function in their lives from very early childhood years (Flexer, Simmons, Luft and Baer, 2013).

\section{How should special education services be for a successful adulthood?}

It is very important for the individuals with developmental disabilities to participate in educational lives and programs which are prepared for them involving independent living skills necessary for their successful adulthood years. Although independent living skills are grouped differently in the international literature, skill areas included in these groupings overlap with each other. General content of these programs consist of basic academic skills, daily living skills, self-determination and interpersonal skills, vocational consulting and preparation for a job skills (Brolin, 1997; Wandry, Wehmeyer and Glor-Scheib, 2013; Wehmeyer and Webb, 2012).

\section{What is the place of a job life in a successful adulthood?}

According to socio-economic variables, participating in a job life can be defined as, a living area which supports independent living of individuals with developmental disabilities, which provides their living in the community as equal and included individuals and which determines their quality of lives (Baer and Daviso, 2013; Rogan, Grossi and Gajewski, 2002). However, when the literature is reviewed, it is reported that, individuals with developmental disabilities face with some problems in job placements and realizing the job life in a sustainable form (Bradley et al., 2015). In a research study Bouck (2012) conducted, the author found that out of all graduated individuals with developmental disabilities from a school, $43 \%$ were placed in a job, hardly $28.4 \%$ of them were in the working life sustainably, and only $12.5 \%$ of them were working in fulltime jobs. In summary, individuals with developmental disabilities work less frequently, with less salary and live as isolated people in the community when compared with typically developing individuals (Carter, Austin and Trainor, 2012). Besides the problems being faced while participating in the working lives, individuals with developmental disabilities who are already in the working lives also face specific problems. Individuals with developmental disabilities work in different conditions when compared with typically developing employees and the business directors prevent their interaction with the customers (Artar, 2018). For this reason, one of the major topics to be handled during transition to adulthood should be career planning and activities (Morningstar and Clavenna-Deane, 2018).

\section{First step to a successful transition to adulthood: Career education}

Career concept refers to the job preferences, competencies and development through the life span which continues parallel to this procedure during whole life (Hall and Mirvis, 1996). Career education is, all the experience of an individual which was framed according to one's preferences and which prepare him/her for a job life. This education aims to help an individual to earn money, spend his spare times and fulfill his responsibilities in the community in every way (Wehmeyer and Webb, 2012). Career education of individuals with developmental disabilities in terms of a successful transition to adulthood both exposes participating in the working life as a basic purpose, and also includes educational activities regarding post school education, taking shelter, participating in the community and developing social relationships (Hanley-Maxvell and Collet-Klingenberg, 2012). Career development can be defined as a procedure which continues all life long, in which a job placement is determined according to an individual's characteristics, and which aims to establish interaction among the individual and the working place reciprocally (Davis and Lofquist, 1984; Holland, 1996). Career development consists of five constitutions related with each other. These are, individual interest and characteristics, conceptual characteristics, mediator characteristics, environmental effects and outputs (Szymanski and Hershenson, 2005).

\section{Career awareness}

Career awareness of individuals with developmental disabilities is one of the most important components of career development and it involves exploring oneself concept on which the process is constructed. Exploring oneself is, the individual's making decisions about how his preferences, community relationships, and other areas of his life will be constructed. The most privileged purpose of individuals with developmental disabilities' career development and vocational training is helping them to explore themselves. Regarding this purpose, during their educational procedure, besides academic skills, different experiences should be provided related with career development and vocational training to individuals with developmental disabilities (Repetto, Webb, Neubert and Curran, 2006; Sitlington, Neubert and Clark, 2010).

\section{Exploring career}

After providing career awareness, it is important to determine the individuals with developmental disabilities' own preferences regarding his/her career. Within this content, first of all, the individual's interests should be determined. In order to do this, role models of the individual, his/her interest topics and hobbies, activities that make him/her happy, individual's favorite stories should be determined and analyzed (Savickas, 2011). In this stage, interviews can be conducted with the individual and/or his/her parents and the individual can be observed in his/her natural environment.

\section{Career preparations}

Career preparations covers the secondary education years vocational skills and job skills are being taught in the working places or at school and mentions the period in which the individual interacts with structured vocational experiences (Morningstar and Clavenna-Deane, 2018). Career preparation includes activities such as (a) determining the basic skills which are expected from all employees in the working environment, (b) acquiring positive attitudes and habits towards work and job, (c) constructing structured experiences for increasing awareness and 
competencies towards different jobs and (d) all kinds of education and training activities for enabling placement into a valuable job sector in the community after the school (Association for Career and Technical Education, 2006).

\section{Career internalizing}

The main purpose of this phase is to place the individual with developmental disability into a job appropriate for his characteristics and maintaining in the job sustainably. Moreover, needed services such as what the individual will do in his spare times after work, where he will shelter should be planned and provided to the individual. During the career internalizing phase, the individuals with developmental disabilities are out of the service coverage area of their schools. Therefore, the close environment, employers, and colleagues are to be thought as natural support resources and necessary precautions should be taken in order for the supports to be high quality to be provided to the individual with developmental disability (Hagner, Dague and Phillips, 2015; Wehman, 2013).

\section{Result and Recommendations}

Individuals with developmental disabilities need qualified education and support services starting from early childhood years to all school period for a successful adulthood life. In the core of these services, there is career education. However, when the literature regarding career education in Turkey is considered, it can be said that, neither service providing personnel nor parents of individuals with developmental disabilities have enough awareness level regarding career education for these people. Therefore, it can be recommended to provide information to parents of individuals with developmental disabilities starting from the diagnosis phase regarding the adulthood years and career development of their child.

In the base of a successful career development, getting to know the individual with developmental disability plays an important role. Determining the individual's interests and preferences, assessing his/her competencies are very important for drawing his life line in his/her adulthood years (Morningstar and Clavenna-Deane, 2018). However, there are not any formal career evaluation tests (e.g., scale, inventory etc.) in Turkey for individuals with developmental disabilities and this constitutes a barrier against career development and referral studies for these people. Therefore, it is very important to develop scales functioning similar to the tests in the international literature or to make adaptation studies into Turkish.

\section{Giriş}

Geçiş, bireyin öğrencilikten toplum içerisinde yaşayan yetişkin rolüne hareket etme süreci olarak nitelendirilebilir. Yetişkinlik dönemindeki bireylerin toplumsal yaşamda gerçekleştirdiği roller; bir işte çalışmak, ev yaşamını bağımsız şekilde sürdürmek, toplumsal yaşama katılmak ve sosyal ilişkiler geliştirmek olarak sıralanabilir. Gelişimsel yetersizliği (zihin yetersizliği ve/veya otizm spektrum bozukluğu) olan bireylerin yetişkinlik dönemine yönelik hayalleri ve istekleri incelendiğinde onların bakış açısından yetişkinlik dönemindeki yaşam kalitesi göstergeleri; üretkenlik, sosyal ilişkiler geliştirme, özerklik ve bağımsızlık elde etme, ekonomik olarak iyi olma ve kendi yaşamını finansal olarak yürütebilme olarak sıralanmaktadır (Brown, Hatton ve Emerson, 2013; Kraemer, Mclntyre ve Blancher, 2003; Wehman, 2013). Okul döneminin sona ermesiyle birlikte gelişimsel yetersizliği olan bireyler kariyer gelişimlerini planlama ve sürdürme, para kazanma ve bütçesini idare edebilme, okul sonrası eğitime katılma, sosyal ilişkiler geliştirme, sağlık durumunu kontrol etme, çalışma yaşamına katılma gibi bağımsız yaşam için gerekli olan birçok sorumlulukla karşı karşıya kalmaktadırlar (Wehmeyer ve Webb, 2012).

Yetişkinliğe geçiş dönemindeki gelişimsel yetersizliği olan bireyler okul sonrası yaşamlarında bir işte çalışmayı ve sosyal bağlar kurarak bunları sürdürmeyi arzu etmektedirler (Cooney, 2002; Cooney, Jahoda, Gumley ve Knott, 2006). Örneğin gelişimsel yetersizliği olan bireylerin çoğu yetişkinlik döneminde gereksinim duydukları alanlarda okul sonrası eğitimlerine devam etmeyi hedeflemektedirler. Ancak bu bireylerin yalnızca \%10'u bu hedefe ulaşabilmektedir (Wagner, Newman, Cameto, Garza ve Levine, 2005). Diğer yandan yetişkinliğe geçiş dönemindeki gelişimsel yetersizliği olan bireyler toplumda yer alan destekleyici sosyal ilişkileri içeren toplumsal çevreyle (gelişimsel yetersizliği olan bireye yeni fırsatlar ve gerektiğinde destek sunan çalışma arkadaşı, akran, komşu vb.) bağ kuramamakta ve bu nedenle çalışma yaşamına katılmak için gerekli fırsatların uzağında kalmaktadırlar (Marshall ve diğ., 2018). Toplumsal dışlanma olarak nitelendirilebilecek bu durum gelişimsel yetersizliği olan bireylerin kariyer gelişimini olumsuz yönde etkilemektedir. Sosyal etkinliklere katılan, sivil toplum kuruluşlarında gönüllü çalışarak toplumsal çevrelerini geliştiren gelişimsel yetersizliği olan bireylerin toplumdan dışlanmış bireylere göre daha yüksek olasılıkla asgari ücretli bir işte çalıştıkları bilinmektedir (Qian, Johnson, Smith ve Papay, 2018). Bu dönemde gelişimsel yetersizliği olan bireyler, okul döneminde sağlanan birçok destekten ve bu destekleri sunan personelden ayrılmakta (Bouck ve Joshi, 2016) ve bağımsız yaşamın gerektirdiği sorumluluklarla etkileşim içerisine girmektedirler. Yetişkin yaşamının gerektirdiği sorumlulukları yerine getirmek için gerekli bilgi, beceri ve davranışlarda eksiklik yaşayan gelişimsel yetersizliği olan bireyler sosyal ve ekonomik açıdan toplumla bütünleşmede sorunlar yaşamaktadırlar (Maclntyre, 2014). Bu nedenle erken çocukluktan itibaren gelişimsel yetersizliği olan bireylerin yetişkinlik yaşamına yönelik planlama ve hazırlık çalışmalarını içeren geçiş hizmetleri oldukça önemli bir işlev taşımaktadır (Flexer, Simmons, Luft ve Baer, 2013).

\section{Başarılı bir yetişkinlik için özel eğitim hizmetleri nasıl olmalı}

Özel eğitim hizmetleri, yetersizliği olan bireylerin işlevsel bilgi ve becerileri öğrenerek yetişkinlik döneminde topluma ve ülke ekonomisine katkıda bulunan üretken bireyler haline gelmesini amaçlamaktadır. Diğer bir deyişle özel eğitim hizmetleri, bu hizmetlerden yararlanan yetersizliği olan bireylerin yetişkinlik dönemindeki yaşam kalitesini arttırmayı amaçlamaktadır (Steere, Rose ve Cavainolo, 2007). Geçiş hizmetlerinin felsefesi, ayrı bir geçiş düzenlemesine gereksinim duyulmaksızın gelişimsel 
yetersizliği olan bireylerin başarılı bir yetişkinlik yaşamına ulaşmasını sağlayacak biçimde özel eğitim hizmetlerinin düzenlenmesini gerektirmektedir (Wehmeyer ve Webb, 2012). Gelişimsel yetersizliği olan bi-reylerin okul döneminde katıldıkları eğitim yaşantılarının ve onlara yönelik programların başarılı bir yetişkinlik için gerekli bağımsız yaşam becerileriyle paralel olması oldukça önemlidir. Uluslararası alanyazında bağımsız yaşam becerileri farklı şekillerde sınıflandırılsa da her sınıflandırmada yer alan beceri alanları birbiriyle örtüşmektedir. Bu eğitim programlarının genel içeriği temel akademik beceriler, günlük yaşam becerileri, öz belirleme ve kişilerarası beceriler, istihdam becerilerinden (işe yerleştirme için gerekli beceriler) oluşmaktadır (Brolin, 1997; Wandry, Wehmeyer ve Glor-Scheib, 2013). Bağımsız yaşam becerilerini sınıflandırmaya yönelik alt beceri alanları Tablo 1'de yer almaktadır.1996).

Tablo 1. Bağımsız yaşam becerileri sınıflandırması

\begin{tabular}{|c|c|c|c|}
\hline Temel Akademik Beceriler & Günlük Yaşam Becerileri & $\begin{array}{l}\text { Öz Belirleme ve Kişilerarası } \\
\text { Beceriler }\end{array}$ & $\begin{array}{l}\text { İstihdam Becerileri } \\
\text { (İşe Yerleştirme İçin Gerekli } \\
\text { Beceriler) }\end{array}$ \\
\hline Okuduğunu anlama & Parayı yönetme & Özgüven kazanma & İş imkanlarını bilme \\
\hline İşlevsel matematik & Evi yönetme & $\begin{array}{l}\text { Sosyal açıdan sorumlu davranışlar } \\
\text { sergileme }\end{array}$ & $\begin{array}{l}\text { Uygun iş alışkanlıkları ve } \\
\text { davranışları sergileme }\end{array}$ \\
\hline \multirow[t]{5}{*}{$\begin{array}{l}\text { İletişim becerileri (Alıcı ve ifade } \\
\text { edici dil) }\end{array}$} & Kişisel bakım & Kişilerarası iyi ilişkiler sürdürme & İş bulma ve işi sürdürme \\
\hline & Aile sorumluluğu geliştirme & Bağımsız kararlar alma & $\begin{array}{l}\text { Yeterli psiko-motor becerileri } \\
\text { sergileme }\end{array}$ \\
\hline & $\begin{array}{l}\text { Yiyecek satın alma-hazırlama- } \\
\text { tüketme }\end{array}$ & Başkalarıyla etkileşimde bulunma & Özel iş becerileri kazanma \\
\hline & Giyecek alma-giyinme & & \\
\hline & $\begin{array}{l}\text { Serbest zamanını } \\
\text { değerlendirme }\end{array}$ & & \\
\hline
\end{tabular}

Tablo 1'de görüldüğü üzere gelişimsel yetersizliği olan bireylerin sahip olması gereken bağımsız yaşam becerileri belli bileşenlerden oluşmaktadır. Gelişimsel yetersizliği olan bireylerin bu bileşenlerin içerisinde yer alan becerilere sahip olmaları onların bağımsızlığına ve toplumla bütünleşmesine katkıda bulunacaktır. Dolayısıyla gelişimsel yetersizliği olan bireyler başarılı ve bağımsız bir yaşam elde edebilmek için bu bileşenlerin desteklenmesine yönelik eğitim ve destek hizmetlere gereksinim duymaktadırlar (Qian, Johnson, Smith ve Papay, 2018).

\section{Başarılı bir yetişkinlikte çalışma yaşamının yeri nedir?}

Sosyo-ekonomik değişkenler açısından çalışma yaşamına katılım, gelişimsel yetersizliği olan bireylerin bağımsız yaşamalarını destekleyen, toplumla bütünleşmiş eşit bireyler olarak yaşamalarını sağlayan ve yaşam kalitelerini belir-leyen önemli bir yaşam alanı olarak nitelendirilebilir (Baer ve Daviso, 2013; Rogan, Grossi ve Gajewski, 2002). Çalışma yaşamı kavramı, iş gücüne katılımı niteleyen istihdam edilme sürecindeki ve işe yerleşme sonrasındaki değişkenler tarafından etkilenen çok boyutlu bir süreçtir. İ̧̧ gücüne katılım sürecinde gelişimsel yetersizliği olan bireyin özellikleri-nin ne tür bir iş yerine uygun olacağının analiz edilmesi istihdam modelleri arasında tercih yapmayı gerektirmektedir. Bununla birlikte, bir işte çalışan gelişimsel yetersizliği olan bireylerin iş yerindeki çalışma koşulları, iş yeri kültürü ve destek sistemleri onların sürdürülebilir şekilde istihdam edilmesinde önemli bir rol oynamaktadır. Ancak alanyazın incelendiğinde gelişimsel yetersizliği olan bireylerin istihdam edilmesinde ve çalışma yaşamını sürdürülebilir şekilde gerçekleştirmesinde sorunlar yaşadığı bilinmektedir (Bradley ve diğ., 2015).

Türk Dil Kurumu (TDK) tarafından tanımlanan istihdam "bir görev, bir işte kullanma" anlamına gelmektedir. Savaşır (1999) istihdam kavramını iş gücünün ekonomik faaliyete katılması olarak tanımlamaktadır. Gelişimsel yetersizliği olan bireyler için çalışma yaşamına katılımın kapılarını aralayan istihdam, tipik gelişen bireylere ve diğer yetersizlik gruplarına göre daha zorlu bir süreç anlamına gelmektedir. Bouck (2012) gerçekleştirdiği çalışmada okuldan mezun olan gelişimsel yetersizliği olan bireylerin \%43.4'ünün bir işe girdiğini, ancak \%28.4'ünün sürdürülebilir şekilde çalışma yaşamında yer aldığını ve sadece \%12.5'inin tam zamanlı bir işte çalıştığını ifade etmiştir. Özetle, gelişimsel yetersizliği olan bireyler okul sonrası yaşamlarında tipik gelişen bireylere göre daha düşük oranla ve ücretle çalışmakta ve toplumdan yalıtılmış şekilde yaşamaktadırlar (Carter, Austin ve Trainor, 2012). Gelişimsel yetersizliği olan bireyler tüm öğrenciler içerisinde okul sonrası yaşam çıktıları açısından en düşük beklentiyle yaklaşılan gruptur (Grigal, Hart ve Migliore, 2011; Grigal, Migliore ve Hart, 2014). Yetersizliği olan bireylerin tipik gelişen bireylerden daha az istihdam edildiği bilinmekteyken (Nittrouer, Pickens ve Shogren, 2015; Türkiye İstatistik Kurumu [TÜiK], 2002), yetersizlik grup-ları içerisinde gelişimsel yetersizliği olan bireyler en az istihdam edilen grubu oluşturmaktadır (Harcourt, Lam ve Har-court, 2005; Sevak, O’Neill, Houtenville ve Brucker, 2018; Wagner, Newman, Cameto, Garza ve Levine, 2005).

Çalışma yaşamına katılımda karşılaşılan bu sorunlara ek olarak hâlihazırda çalışma yaşamının içinde olan gelişimsel yetersizliği olan bireyler de belli sorunlar yaşamaktadırlar. Gelişimsel yetersizliği olan çalışanlar iş yerlerinde tipik gelişen çalışanlardan farklı koşullarda çalışmakta ve iş yeri yönetimleri tarafından müşterilerle etkileşime girmelerinin önüne geçilmektedir (Artar, 2018). Bununla birlikte, gelişimsel yetersizliği olan çalışanlar iş yerlerinde genellikle yinele-yici ve basit işlerden sorumlu tutulmaktadırlar. Bu durum, onların kariyer gelişimleri, iş doyumları ve çalışmaya yöne-lik tutumları üzerinde olumsuz etkiye sahiptir (Ferrari, Nota 
ve Soresi, 2005). Özetle, özel eğitim hizmetlerinden yarar-lanan gelişimsel yetersizliği olan bireylerin sayısı her geçen yıl artmakla birlikte, toplum temelli çalışma yaşamına katı-lan bireylerin sayısının sabit kaldığı görülmektedir (Bradley ve diğ., 2015).

Gelişimsel yetersizliği olan bireylerin çalışma yaşamında elde edecekleri çıktılar, onların istihdam edilme şekilleriyle bire bir ilişkilidir (Bradley ve diğ., 2015). Örneğin rekabetçi istihdam modeline göre çalışma yaşamına katılan bireylerin sosyal katılımı ve aldıkları maaş, korumalı işyerinde çalışan bireylere göre daha yüksektir. Amerika Birleşik Devletle-ri'nde (ABD) gerçekleştirilen Ulusal Temel Göstergeler Araştırması'nın (National Core Indicator) bulguları gelişimsel yetersizliği olan bireylerin genellikle korumalı işyerlerinde ve ücret almaksızın çalıştıklarını göstermektedir (Bradley ve diğ., 2015). Bu durum, alanyazında bireyden kaynaklı ve çevresel koşullardan kaynaklı engeller olarak belirtilmektedir. Bireyden kaynaklı engeller, gelişimsel yetersizliği olan bireyin çalışma yaşamına yönelik ilgi ve tercih geliştirmemesi ve bir işte çalışmak için gerekli meslek öncesi ve mesleki becerilere sahip olmaması olarak ifade edilmektedir. Çevresel koşullardan kaynaklı engeller, gelişimsel yetersizliği olan bireylerin özelliklerine yönelik toplumdaki ve özellikle işveren-lerdeki olumsuz tutumlar, bilgi eksiklikleri ve önyargılar olarak sıralanmaktadır (Nittrouer, Pickens ve Shogren, 2015).

Çalışan yeterlikleri, çalışma yaşamına katılım ve sürdürülebilir şekilde çalışma için oldukça önemlidir. Ancak geli-şimsel yetersizliği olan bireylerin aldıkları iş ve meslek eğitiminin işveren beklentilerinden ve bölgedeki iş olanakların-dan kopuk şekilde gerçekleşmesi bu bireylerin çalışma yaşamına katılımının önünde bir engel oluşturmaktadır (Eche-vin, 2013). Çalışma yaşamının gelişimsel yetersizliği olan bireylerin yaşam kaliteleri üzerindeki önemli etkisi göz önün-de bulundurulduğunda, bu bireylerin oldukça karmaşık ve çok boyutlu bir süreç olan çalışma yaşamına katılmaları ve sürdürülebilir şekilde çalışabilmeleri erken çocukluk döneminden itibaren gerçekleştirilecek çalışmalarla mümkün ola-caktır. Bu nedenle gelişimsel yetersizliği olan bireyler için yetişkinliğe geçiş çalışmaları kapsamında göz önünde bulun-durulması gereken alanların başında kariyer planlaması ve etkinlikleri gelmektedir (Morningstar ve Clavenna-Deane, 2018).

\section{Yetişkinliğe başarılı bir geçiş için ilk adım: Kariyer eğitimi}

Kariyer kavramı tüm yaşam boyunca süren mesleki tercihler, yeterlikler ve bu süreçle paralel ilerleyen yaşam boyu gelişimi nitelendirmektedir (Hall ve Mirvis, 1996). Kariyer gelişimi çalışmaları sadece mesleki gelişimle ilgili olmayan, ancak mesleki eğitime temel oluşturan çalışmaları kapsamaktadır. Bu konuda öncü çalışmalar gerçekleştiren Dewey, eğitim program ve süreçlerinin sadece akademik becerilerden oluşmaması, eğitim sisteminin bireyi bağımsızlığa ve çalışma yaşamına taşıyacak mesleki becerileri de kapsaması gerektiğini ifade etmiştir. Kariyer eğitimi, bireyi kendi tercihi doğrultusunda çerçevesi çizilen ve çalışma yaşamına hazırlayan deneyimlerin tümüdür. Bu eğitim, bireylerin gelir elde etmesini, serbest zamanlarını değerlendirmesini ve her yönüyle yurttaşlığın sorumluluklarını yerine getirmesini amaçlamaktadır (Wehmeyer ve Webb, 2012). Kariyer eğitimi yıllar içerisinde ABD'deki geçiş çalışmalarının odağını oluşturmuştur. Gelişimsel yetersizliği olan bireylerin yetişkinliğe başarılı geçişi kapsamında kariyer eğitimi, çalışma yaşamına katılımı temel hedef olarak ortaya koymakla birlikte, bu hedefe ulaşmak amacıyla gerçekleştirilecek okul sonrası eğitim, barınma, toplumsal yaşama katılım ve sosyal ilişkiler geliştirme alanlarına yönelik eğitim etkinliklerini kapsamaktadır (Hanley-Maxvell ve Collet-Klingenberg, 2012). Özetle kariyer eğitiminin amacı, gelişimsel yetersizliği olan bireylerin kariyer gelişimlerinin desteklenmesidir.

Kariyer gelişimi; yaşam boyunca devam eden, birey özelliklerine en uygun çalışma ortamının belirlenmesini, birey ile çalışma ortamı arasında karşılıklı bir etkileşim kurulmasını amaçlayan bir süreç olarak nitelendirilebilir (Davis ve Lofquist, 1984; Holland, 1996). Kariyer gelişimi kavramı birbiriyle ilişkili beş yapıdan oluşmaktadır. Bunlar bireysel ilgi ve özellikler, bağlamsal özellikler, aracı etmenler, çevresel etkiler ve çıktılar olarak sıralanabilir. Bireysel ilgi ve özellik-ler; cinsiyet, yeterlikler, ilgiler ve benimsenen değerler vb. özellikleri içermektedir. Bağlamsal özellikler; sosyo-ekonomik durumlar, eğitim fırsatları, yasal düzenlemeler gibi değişkenleri nitelendirmektedir. Aracı etmenler, bireyin kendisine yönelik farkındalık düzeyiyle toplumun birey kimliğine yönelik kültürel ve sosyal inançlarının uyumuyla açıklanabilir. Çevresel etkiler, çalışma ortamlarında karşılaşılan çalışma koşulları ve diğer özellikleri içeren değişkenleri içermektedir. Son olarak çıktılar, çalışma yaşamından elde edilen doyum, üretkenlik, stres ya da sosyal güvenlik kazanımları olarak sıralanabilir (Szymanski ve Hershenson, 2005).

Kariyer gelişimi çalışma yaşamına uyum sağlamak için gerekli yeterliklerin belirlenmesini gerektirmektedir. Bir işte çalışmak için gerekli yeterlikler çalışma alışkanlıklarına sahip olma, çalışma yetkinliğine sahip olma ve iş hedeflerine ulaşma şeklinde sıralanabilir. $\mathrm{Bu}$ yeterliklerin gelişimsel yetersizliği olan bireylere kazandırılması uzun dönemli bir plan-lamayı gerektirmektedir. Gelişimsel yetersizliği olan bireylerin çalışma alışkanlıklarına sahip olması için gerçekleştirile-cek çalışmalar okul öncesi dönemden başlamaktadır (Hanley-Maxvell ve Collent-Klingenberg, 2012). Örneğin okula zamanında gelme, ödevlerini zamanında ve beklenen nitelikte tamamlama gibi yeterlikler çalışma alışkanlıkları için ön koşul niteliği taşımaktadır. Gelişimsel yetersizliği olan bireyin çalışma yeterliklerine sahip olması için gerçekleştirilecek çalışmalarsa okul dönemi boyunca gerçekleştirilecek her türlü eğitim sürecini kapsamaktadır. Bireyin ne tür mes-leklere ilgi duyduğunun ve bu meslekleri yerine getirmek için gerekli mesleki becerilerin neler olduğunun ortaya konarak bunlara yönelik gerçekleştirilen çalışmalar çalışma yeterliklerini arttırmayı hedeflemektedir. Son olarak okul dönemi sonrasında gelişimsel yetersizliği olan bireyin yerleştirileceği işte kendisinden beklenen iş becerilerinin ortaya konarak buna yönelik iş başında ya da kurum temelli olarak sağlanan eğitim hizmetleri de iş hedeflerine ulaşma çalışmaları kapsamında okul sonrası dönemde gerçekleştirilebilir (Leake ve Black, 2005). Kariyer gelişimi süreci, gelişimsel yetersizliği olan bireylerin kariyer kavramına yönelik farkındalık oluşturması, kendi kariyer süreçlerine yönelik ilgi ve isteklerinin keşfedilmesi, bireyin yeterliklerine ve gereksinimlerine uygun olarak kariyer hazırlığı ve kariyerin özümsenmesi aşamalarından oluşmaktadır 
(Wehmeyer ve Webb, 2012). Bu aşamalar aşağıda Şekil 1'de yer almaktadır. Aşağıda bu aşamaların her birine ilişkin açıklamalara yer verilmiştir.

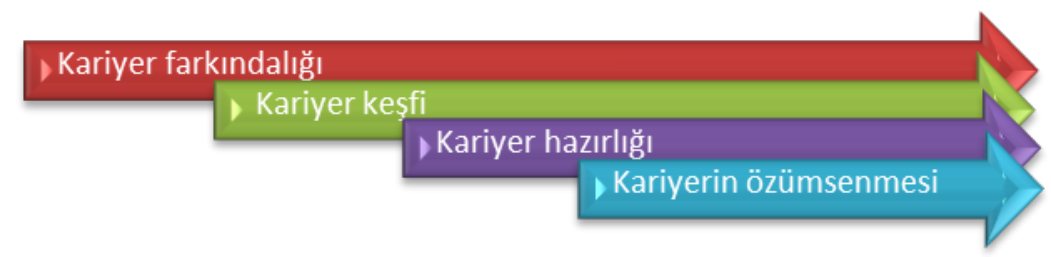

\section{Şekil 1. Kariyer gelişimi süreci}

\section{Kariyer farkındalı̆̆}

Gelişimsel yetersizliği olan bireylerin kariyer farkındalığı, kariyer gelişiminin en önemli bileşenlerinden olan ve sü-recin üzerine kurulduğu kendini keşfetme kavramını içermektedir. Kendini keşfetme, bireyin çalışma yaşamına yönelik tercihlerinin, toplumsal ilişkilerinin ve yaşamının diğer alanlarının ne şekilde düzenleneceğine ilişkin kararlar almasıdır. Gelişimsel yetersizliği olan bireylerin kariyer gelişimi ve mesleki eğitimlerinde en öncelikli amaç onların kendini keşfetmesini sağlamaktır. Bu amaç doğrultusunda bireye eğitim sürecinde akademik becerilerin yanında kariyer gelişimi ve mesleki eğitimle ilgili farklı deneyimler yaşatılmalıdır (Repetto, Webb, Neubert ve Curran, 2006; Sitlington, Neubert ve Clark, 2010). Bu deneyimler bireylerin gelecekte çalışma yaşamında ne gibi roller üstleneceğine ve hangi sektörlerde çalışmaya uygun olduğunu belirlemeye yönelik eğitimcilere fırsatlar sunabilir (Meaker, 2016). Bu doğrultu-da gelişimsel yetersizliği olan bireylerin ilkokul ve ortaokul döneminde farklı iş yerlerini ziyaret etmeleri ve buradaki çalışanlarla etkileşim kurmaları sağlanabilir. Bununla birlikte, çeşitli iş alanlarında faaliyet gösteren işverenler ve çalışanlar sınıfa davet edilerek gelişimsel yetersizliği olan bireylerle etkileşimde bulunmaları sağlanabilir. Bu uygulama-lar, gelişimsel yetersizliği olan bireylerin kariyer farkındalığını arttırmanın yanı sıra, işverenlerin ve tipik gelişen çalışanların tutumlarında da olumlu değişimler yaratabilmektedir.

Gelişimsel yetersizliği olan bireylerin kendini keşfetmesi, mesleki eğitime yönelik motivasyonlarını artırmaktadır. Diğer bir deyişle kendini keşfetmeyle birlikte birey, okuldaki öğrenme etkinlikleriyle gelecekteki kariyer hedeflerini bağdaştırmaktadır. Gelişimsel yetersizliği olan bireylerin kariyer farkındalığının artması onların ve ailelerinin eğitim yaşantılarının yolunu çizmesinde oldukça önemlidir. Kariyer sürecinin farkında olan birey ve ailesi, geleceğe yönelik bir bakış açısı geliştirecek ve eğitim hizmetlerine bu gözle bakacaktır. Bununla birlikte, başarılı bir kariyer süreci için tüm paydaşlar bireyin sahip olması gereken yeterliklerin de farkında olacak ve kariyerin önemli bir bileşeni olan çalışma yaşamına katılım için gerekli yeterlikleri araştırarak (örn., diploma, sertifika vb.) bu yeterliklerin kazanılması adına girişimlerde (örn., okul sonrası eğitim programları, yaygın eğitim programları vb.) bulunacaklardır (Thurlow, Cormier ve Vang, 2009). Gelişimsel yetersizliği olan bireylerin gelecek yaşamına yönelik amaç ve idealleri ile kariyer farkındalığı arasında kurulacak köprü aynı zamanda bireyin eğitim yaşantılarını anlamlandırmasını sağlayacaktır (Wehmeyer ve Webb, 2012).

Gelişimsel yetersizliği olan bireylere kariyer farkındalığı kazandırmak amacıyla ilkokul yıllarından itibaren farklı mesleklere ilişkin roller ve mesleklerin yerine getirdiği işlevler öğretilebilir. Mesleklerin öğretimi kariyer farkındalığı ka-zandırmak için iyi bir başlangıç olarak nitelendirilebilir (Loyd ve Brolin, 1997). Kariyer farkındalığı aşamasında gelişimsel yetersizliği olan bireylerin çalışma yaşamındaki rutinlere uyumu ve çalışma arkadaşlarından alınan destekler gibi doğal desteklere ulaşımı için gerekli altyapı da oluşturulmalıdır. Bu doğrultuda kariyer gelişiminin desteklenmesi amacıyla okul döneminden itibaren gelişimsel yetersizliği olan bireylerin ilgi ve yeteneklerini keşfetmeleri, farklı iş ve mesleklerle etkileşim kurmaları ve toplumsal yaşamın farklı alanlarında deneyimler elde etmeleri sağlanmalıdır (Sitlington, Neubert ve Clark, 2010; Weidenthal ve Kochar-Bryant, 2007).

\section{Kariyer keşfi}

Kariyer farkındalığı sağlandıktan sonra gelişimsel yetersizliği olan bireylerin kendi kariyerlerine yönelik tercihlerinin belirlenmesi önemlidir. Bu kapsamda öncelikle bireyin ilgileri ortaya konmalıdır. Bunun için bireyin rol modelleri, ilgi duyduğu konular ve hobiler, bireyin yapmaktan mutlu olduğu etkinlikler, bireyin en sevdiği hikâyeler belirlenerek analiz edilmelidir (Savickas, 2011). Bu aşamada birey ve ailesiyle görüşmeler yapılabilir, birey doğal ortamında gözlenebilir.

Gelişimsel yetersizliği olan bireylerin kariyere yönelik tercihleri çalışma yaşamı kapsamında da düşünülmelidir. Örneğin insanlarla iletişim kurmayı seven bir birey için çalışma yaşamında toplum temelli bir işte çalışması ve insanla ilişki içeren işlerle (örn., servis elemanı, hostes vb.) ilgili görevlerde yer alması amaç olarak belirlenebilir. Kariyer ve çalışma yaşamı arasında bağ kurmak, kariyer gelişimi süreciyle birlikte mesleki gelişim sürecini de düşünmeyi gerektirmektedir. Bu kapsamda kariyere ilişkin tercihler çalışma yaşamına ilişkin bileşenlere yönelik tercihler için de önemli bir yordayıcı olarak nitelendirilebilir. Gelişimsel yetersizliği olan bireylerin kariyer keşfi çalışmaları kapsamında hem bireyin hem de çevresel değişkenlerin değerlendirildiği bir sürecin işletilmesi oldukça önemlidir. 


\section{Çevresel değerlendirme}

Çevresel değerlendirme, gelişimsel yetersizliği olan bireyin sahip olduğu yeterliklerin ve bireyden halihazırda devam ettiği ya da gelecekte katılması öngörülen eğitim etkinlikleri, çalışma yaşamı, barınma alternatifleri ve toplumsal yaşamda beklenen yeterliklerin bir arada düşünülerek değerlendirme yapılmasını nitelendirmektedir (Miller, Lombard ve Corbey, 2007). Bu doğrultuda çevresel değerlendirme, birey yeterlikleriyle çevresel değişkenler arasında bağ ku-rulmasını ve gelişimsel yetersizliği olan bireye sunulacak hizmetlerin bu temel doğrultusunda sunulması için gerekli amaçları oluşturmaktadır (Bradley ve diğ., 2015). Çevresel değerlendirme; (a) bireyin gereksinim duyacağı potansiyel becerilerin, (b) bireyin gerçek yaşamda kullanacağı becerilerle birey ve çevresindeki kişilerin (örn., ebeveynler, olası çalışma arkadaşları, iş verenler vb.) önemsediği becerilerin ve (c) çevresel desteklerin belirlenmesini içermektedir.

Bireyin gereksinim duyacağı potansiyel becerilerin değerlendirilmesinde belli bir görevle ilgili beceriler, önemli yaşam alanlarında gereksinim duyulan sosyal beceriler ve bireyin ileride etkileşim kuracağı iş yeri, okul sonrası eğitim ortamları gibi hedef bağlamlarda gereksinim duyması öngörülen bütünleştirici becerilerin değerlendirilmesi gerçekleştirilmektedir. Bu doğrultuda iş yerlerinde ya da bireyin yetişkinlik yaşamında etkileşim kuracağı ortamlarda gözlemler gerçekleştirilerek bu ortamlarda sergilenmesi gereken beceriler belirlenmektedir. Bununla birlikte, belirlenen bu ortamlarda yer alan işveren, çalışma arkadaşları gibi kişilerle gerçekleştirilecek görüşmelerden elde edilen veriler gelişimsel yetersizliği olan bireylerin sahip olması gereken yeterliklere yönelik değerlendirme sürecini destekleyecektir (Hanley-Maxwell ve Collet-Klingenberg, 2012). Elde edilen bu veriler gelişimsel yetersizliği olan bireyin devam ettiği eğitim programıyla birlikte değerlendirilerek gerekli düzenlemelerin gerçekleştirilmesi gerekmektedir. Kariyer gelişimi için önemli olan bu beceriler alanyazında bağımsız yaşam becerileri olarak da nitelendirilmektedir. Bağımsız yaşam becerileri Tablo 2'de paylaşılmıştır.

Tablo 2. Bağımsız yaşam için gerekli beceriler

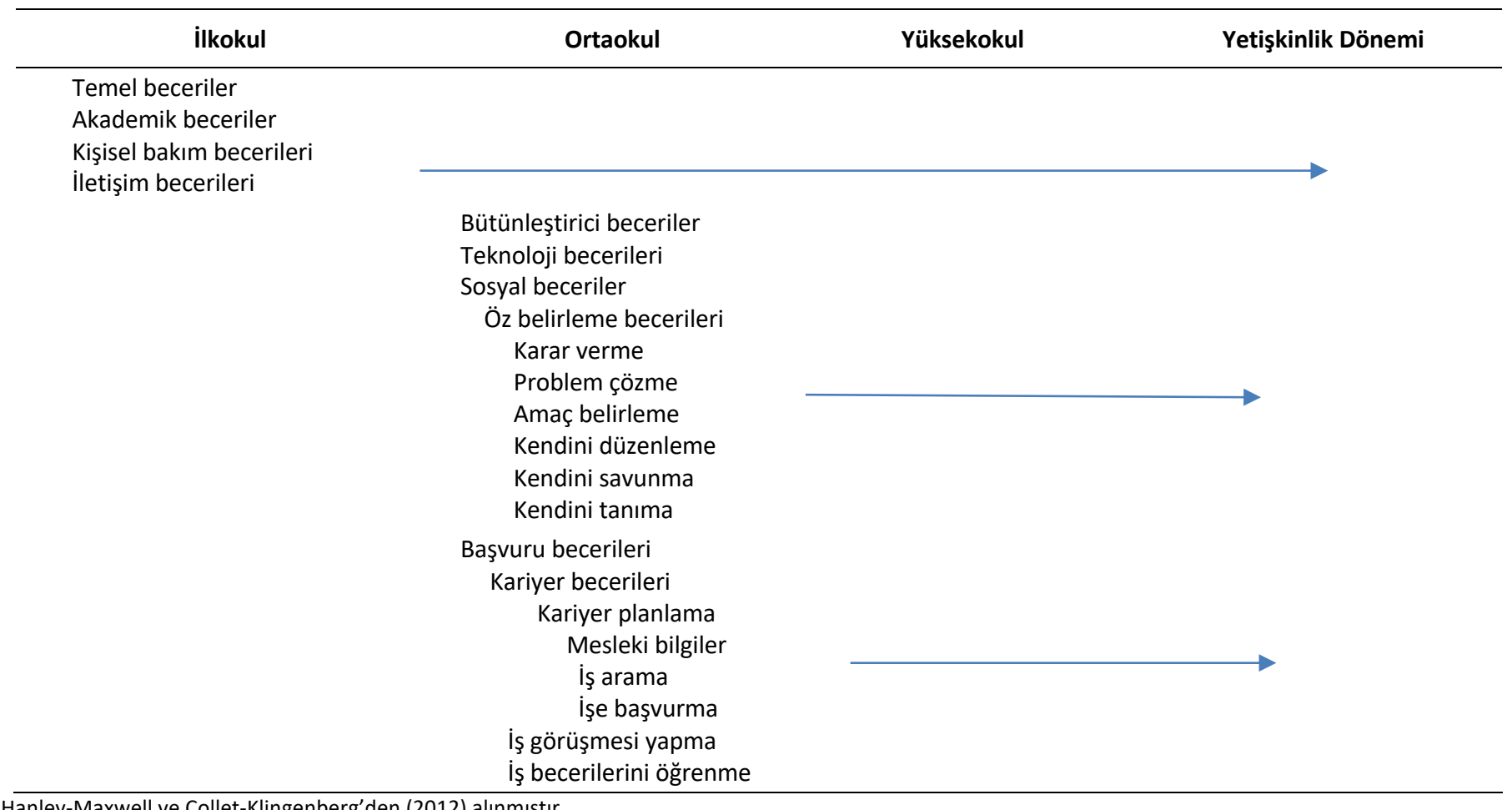

Hanley-Maxwell ve Collet-Klingenberg'den (2012) alınmıştır.

Potansiyel becerilere yönelik gerçekleştirilen değerlendirme sonrasında ortaya çıkan gereksinim alanlarında gelişimsel yetersizliği olan bireyin düzeyinin belirlenmesi için bireysel değerlendirme süreci işletilmelidir. Bireysel değerlendirme, yetişkinlik yaşamında bireyin sergilemesi gereken beceriler ve sahip olması gereken yeterlikler kapsamında gerçekleştirilmektedir. Bu doğrultuda gerçekleştirilecek değerlendirmeler kontrol listeleri, anketler, ölçekler vb. kullanılarak gerçekleştirilebileceği gibi bunların olmaması durumunda nitelikli hazırlanmış bireyselleştirilmiş eğitim programına (BEP) dayalı değerlendirmeler yoluyla da gerçekleştirilebilir. Böylece, bireyin kendisinden beklenen yeterliklere ne derece uyum sağladığı ortaya konabilir. Diğer yandan gelişimsel yetersizliği olan bireyler de tıpkı tipik gelişen bireyler gibi farklı kişilik özelliklerine sahiptirler. Bu nedenle kariyer keşfine yönelik çalışmalar kapsamında birey özelliklerinin ve mesleklerin gerektirdiği kişilik özelliklerinin ortaya konması oldukça önemlidir (Meaker, 2016). Tablo 3'de kişilik özellikleri ve bu özelliklerle eşleştirilen meslek türleri yer almaktadır.

Çevresel destek sistemlerinin değerlendirilmesi gelişimsel yetersizliği olan bireyin başarılı bir yetişkinlik yaşamına ulaşması için gereksinim duyabileceği olası desteklerin belirlenmesidir. Bu destekler yetişkinlik hizmetlerini sunan ku-rumlar, çalışma yaşamındaki destekler, devlet politikaları ve yasal düzenlemeleri içermektedir (Wehman ve Bricout, 2001). Bu kapsamda destekleyici bir çevre oluşturmak adına bireyin bulunduğu çevrenin durumunun ortaya konması amaçlanmalıdır. Çevrenin durumunun ortaya konması kapsamında çevrenin erişilebilirlik açısından değerlendirilmesi, bireye toplumda sağlanan doğal desteklerin belirlenmesi, yetişkinlik yaşamındaki kritik alanlarda (örn., istihdam, iş güvenliği, sosyal güvenlik sistemi vb.) 
uygulamaları düzenleyen yasal metinlerin değerlendirilmesi gerekmektedir (Han-ley-Maxvell ve Collet-Klingenberg, 2012). Bireyin ve çevrenin değerlendirilmesi sonrasında elde edilen veriler birey, ebeveynleri ve hizmet sunanların katıldığı karar alma süreçlerinde değerlendirilerek kariyer hazırlığı çalışmalarının çerçevesinin çizilmesinde önemli bir kaynak oluşturacaktır.

Tablo 3. Kişilik özellikleri ve meslek türlerinin eşleştirilmesi

\begin{tabular}{lll}
\hline Kişilik Özellikleri & Tanımlama & Meslek Türleri \\
\hline Gerçekçi & $\begin{array}{l}\text { Pratik ve beden gücüne dayalı görevleri yerine getirmekten } \\
\text { hoşlanan bireyler }\end{array}$ & $\begin{array}{l}\text { Elektrik teknisyeni, fotoğrafçı, otopark } \\
\text { görevlisi vb. }\end{array}$ \\
Araştırmacı & $\begin{array}{l}\text { Fiziksel etkinlikler ve diğer bireylerle çalışmaktan ziyade } \\
\text { fikirler ve düşünceler üzerine çalışmaktan hoşlanan bireyler }\end{array}$ & $\begin{array}{l}\text { Kimyacı, matematikçi, laboratuar teknisyeni, } \\
\text { bilgisayar işletmeni vb. }\end{array}$ \\
Sanatçı & Tasarım, müzik, sanat ve oyunculuktan hoşlanan bireyler & $\begin{array}{l}\text { Heykeltraş, ressam, yazar, oyuncu, öğretmen } \\
\text { vb. }\end{array}$ \\
Sosyal & $\begin{array}{l}\text { Diğerlerine yardım etmekten ve onlardan yardım almaktan } \\
\text { hoşlanan bireyler }\end{array}$ & $\begin{array}{l}\text { Öğretmen, akademisyen, sosyal çalışmacı, } \\
\text { danışman vb. }\end{array}$ \\
Girişimci & İş projelerine başlayan ve bu projeleri sürdüren bireyler & $\begin{array}{l}\text { Emlakçı, avukat, yönetici vb. } \\
\text { Belli ve kalıplaşmış görevleri yerine getirmekten hoşlanan }\end{array}$ \\
bireyler & $\begin{array}{l}\text { Kütüphaneci, müşteri hizmetleri danışmanı, } \\
\text { sekreterlik ve büro işleri vb. }\end{array}$
\end{tabular}

\section{Kariyer hazırlığı}

Kariyer hazırlığı ortaöğretim sürecini kapsayan ve gelişimsel yetersizliği olan bireye mesleki becerilerin, iş becerileri-nin iş başında ya da okulda öğretiminin sağlandığı ve bireyin yapılandırılmış iş deneyimleriyle etkileşim kurduğu dö-nemi ifade etmektedir (Morningstar ve Clavenna-Deane, 2018). Bu dönemde kariyer eğitimi çalışmalarının kapsamı daralmaktadır. Mesleki eğitim olarak nitelendirilebilecek çalışmaların gerçekleştirildiği bu dönemde ana amaç, gelişim-sel yetersizliği olan bireyin çalışma yaşamında başarılı olmak için gereksinim duyduğu yeterlikleri kazanması olarak ifade edilebilir (Wehmeyer ve Webb, 2012). Kariyer hazırlığı; (a) çalışma yaşamında çalışanlardan beklenen temel becerilerin belirlenmesini ve öğretimini, (b) bireye işe ve çalışmaya yönelik olumlu tutum ve alışkanlıkların kazandırıl-masını, (c) farklı mesleklere yönelik yeterlikleri ve farkındalığı arttıracak yapılandırılmış deneyimlerin oluşturulmasını ve (d) okul sonrası dönemde toplumda değeri olan bir sektörde iş gücüne yerleştirmeyi kolaylaştıracak her türlü eğitim ve öğretim etkinliklerini içermektedir (Association for Career and Technical Education, 2006).

Mesleki gelişim tipik gelişen bireyler için yaşam boyu devam eden bir süreçtir. Tipik gelişen bireyler kariyer gelişimlerini desteklemek için farklı kurs ve seminerler yoluyla mesleki yeterliklerini destekleyebilmekte, toplumsal çevreleri yoluyla kendilerine en uygun iş olanaklarıyla etkileşim kurabilmektedirler. Buna karşın gelişimsel yetersizliği olan bireyler okul sonrası yaşamlarında genellikle okulun sağladığı desteklerin dışında kalmakta ve gereksinimleri doğrultusunda desteklenmemektedirler (Benz, Lindstrom ve Yovanoff, 2000). Bu nedenle okul dönemi içerisinde gelişimsel yetersizliği olan bireylerin mesleki gelişimlerinin desteklenmesi oldukça önemlidir.

Okul döneminde gelişimsel yetersizliği olan bireylere yönelik kariyer hazırlığı çalışmaları onların çalışma yaşamına yönelik beklentilerini gerçekçi hale getirerek yetişkinlik yaşamına yönelik daha sağlıklı kararlar alınmasını sağlamak-tadır. Kariyer hazırlığı çalışmaları kapsamında öncelikle bireye okulda sunulan programların gözden geçirilmesi ge-rekmektedir. Öğretmenler ve okul yönetimleri, okullarında hâlihazırda hizmet sunan iş atölyelerinin niteliğini ve bu atölyelerin hangi meslek alanına hizmet ettiğini değerlendirmelidirler. Gerçekleştirilen değerlendirme sonucunda okulda eğitimi sunulan meslek alanları (örn., ciltleme, tekstil, büro yönetimi vb.) listelenmelidir. Ardından okulda sunulan mesleki eğitim hizmetleriyle içinde yaşanılan çevredeki iş olanakları bir arada düşünülmelidir. Bu kapsamda yaşanan yerin büyüklüğüne göre gözlem ve görüşmeler içeren saha çalışmalarıyla gelişimsel yetersizliği olan bireyin çalışabileceği potansiyel çalışma ortamları ortaya konmalıdır (Morgan ve Riesen, 2016).

Potansiyel çalışma ortamlarının belirlenmesi sürecinde çalışma ortamları; çalışanlardan beklenen görevler, çalışma koşulları, iş yerinin fiziksel özellikleri ve işin potansiyel getirileri açısından değerlendirilmelidir. Her iş yerinin yapısı ve o iş yerinde çalışanlardan beklenen görevler farklılık göstermektedir. Kimi iş yerlerinde rutin ve yineleyici işler gerçekleştirilirken (örn., montaj işleri, imalat işleri vb.) kimi iş yerlerinde gerçekleştirilen işler insanlarla etkileşim kurmayı (örn., garsonluk, kasiyerlik vb.) gerektirmektedir. ífade edici dil becerilerinde sınırlılık yaşayan gelişimsel yetersizliği olan bireyin lokantada garson olarak çalışması durumunda başarısız olacağı öngörülebilir. Bu nedenle iş ortamlarında çalışanlardan beklenen görevlerin belirlenmesi oldukça önemlidir. Çalışma koşulları iş yerindeki çalışma saatlerini, vardiya rejimini ve iş yeri kültürünü içeren durumları ifade etmektedir. Çalışanların çalışma koşullarına uygunluğu, onların iş tatminini ve performansını önemli düzeyde etkilemektedir. Örneğin iş yerlerinde gözlenen iş yeri kültürü çalışma yaşamının sağlayacağı sosyal katılımı etkileyen doğal bir değişken olarak nitelendirilebilir (Hagner, 1992; Hag-ner, Gague ve Philips, 2015). Kurumsal ve büyük ölçekli iş yerlerinde çalışanların diğer çalışanlar ve müşterilerle etkileşiminin sınırlı 
olduğu, diğer yandan küçük ölçekli işletmelerde çalışanlar arasında arkadaşlık bağının gelişmesi için daha uygun bir ortam olduğu söylenebilir (Artar, 2018). İş yerlerinin fiziksel özellikleri ve konumu da potansiyel çalışma ortamlarının belirlenmesinde önemli bir bileşendir. Bu kapsamda iş yerlerinin erişilebilirlik, gelişimsel yetersizliği olan bireyin evine yakınlık gibi değişkenler açısından incelenmesi önemlidir. Son olarak çalışma ortamları çalışanların kazandığı maaş ve onlara sunulan kariyer fırsatları (örn., görevde yükselme, işten çıkarılma vb.) açısından değerlendirilmelidir (Yost ve Corbishley, 1987).

Potansiyel çalışma ortamlarının özelliklerinin ortaya konmasının ardından bu iş yerlerinin çalışanlarından beklediği beceri ve tutumlar hakkında bilgi edinilmelidir. Ardından gelişimsel yetersizliği olan bireyin de aktif katılım sağladığı bir süreç sonunda hangi alanda kariyer hazırlığı çalışmalarının gerçekleştirileceğine karar verilmelidir. Bu aşamada bireyle birlikte ilgili iş yerlerinin gezilmesi doğru karar vermede önemli rol oynamaktadır (Wehmeyer ve Webb, 2012).

Gerçekleştirilen araştırmalar okul döneminde herhangi bir işte deneyim yaşayan gelişimsel yetersizliği olan bireylerin okul sonrasında işe girme olasılığının önemli düzeyde arttığını göstermektedir (Rabren, Dunn ve Chambers, 2002). Okul döneminde gerçekleştirilen mesleğe hazırlık çalışmaları gelişimsel yetersizliği olan bireylerin kariyer seçeneklerini keşfetmelerini, belli işlere yönelik iş becerilerini geliştirerek uygulamalarını, işe ve çalışmaya yönelik olumlu tutum geliştirmelerini sağlamaktadır (Doren, Lindstorm, Zane ve Johnson, 2007). Gelişimsel yetersizliği olan bireyin okul döneminde mesleki deneyimler elde etmesi onların iş başında eğitim yaklaşımıyla yeterliklerinin arttırımasına olanak sağlamaktadır. İş başında eğitim, gelişimsel yetersizliği olan bireylerin çalışma yaşamına hazırlanmasında en etkili yollar-dan biridir (Benz, Lindstrom ve Yovanoff, 2000). Gelişimsel yetersizliği olan bireylerin mesleki deneyim elde etmesi için sınırlı destekten yoğun desteğe kadar birçok mesleki deneyim seçeneği bulunmaktadır. Bunlar gölge çalışanlık, gönüllü çalışma, okul temelli girişimler, stajyerlik, çıraklık ve ücretli çalışma olarak sıralanabilir (Lindstrom, Benz ve Doren, 2004). Gölge çalışan uygulaması, gelişimsel yetersizliği olan bireyin ilgi ve yeterlikleri doğrultusunda bir iş yerindeki gönüllü ve deneyimli çalışanla eşleştirilmesini içermektedir. Gelişimsel yetersizliği olan birey bu uygulama kapsamında gün boyunca bu çalışanın gerçekleştirdiği işleri gözlemektedir (Luecking, 2009). Gölge çalışanlık uygulamasında gelişimsel yetersizliği olan bireyin deneyimi sınırlı olmasına rağmen süreçte eğitimini aldığı meslekler hakkında bir fikir edinmektedir. Bu uygulama kapsamında gelişimsel yetersizliği olan bireylerin birçok kariyer alanında kısa süreli dene-yimler elde etmesi, iş yeri kültürü ve iş yeri rutinleri hakkında bilgi sahibi olması ve böylece çalışma yaşamına yönelik tercihlerini gözden geçirmesi sağlanabilir. Gönüllü çalışma, toplumsal bağların güçlendirilmesi, vatandaşlık sorumluluğu kazandırma ve deneyim elde etme amacıyla toplum tarafından değer gören işlerin ücretsiz ve bir süreliğine gönüllü olarak gerçekleştirilmesidir. Gönüllü çalışma alanları, okulda yürütülen öğrenme etkinlikleri göz önünde bulundurula-rak belirlenmelidir. Örneğin ciltleme atölyesinde çalışan ve kâğıt yapımı konusunda ders alan öğrenciler bir hafta bo-yunca geri dönüşüm fabrikasında öğretmenleri eşliğinde deneyim elde edebilirler. Böylece, hem okul etkinlikleri destek-lenmekte hem de gelişimsel yetersizliği olan bireyin iş dünyasıyla bağ kurması sağlanmaktadır (O'Connor, 2009). Okul temelli girişimler, okul programıyla birlikte devam eden ve üretime odaklı işlerin öğrenciler tarafından yürütülmesi olarak tanımlanabilir (Wehmeyer ve Webb, 2012). Bu tür iş deneyimleri gelişimsel yetersizliği olan bireyin çalışma yaşamına geçiş yapmadan önce iş becerilerini geliştirmek için oldukça önemlidir. Okul temelli girişimler hem okul ortamının güvenliğini hem de çalışma yaşamının gerektirdiği sorumlulukların edinilmesini sağlamaktadır. Bu süreçte okul yönetimi öğrencilerin ulaşımının kolaylıkla sağlanabileceği bir alanı kiralar/satın alır. Bu alanda toplum tarafından gereksinim duyulan $\mathrm{mal} /$ hizmetleri üretir. Elde edilen gelir öğrencilere ya da okulun gereksinimlerine katkı sağlar. Bir iş ve meslek okulunun bahçesine kafeterya açarak kurulu olduğu mahalle sakinlerine hizmet vermesi bu sürece örnek olarak gösterilebilir. Staj uygulaması, ücretli ya da ücretsiz olarak gerçekleştirilen, uzun dönemli ve yapılandırılmış mesleki deneyimler olarak tanımlanabilir. Staj uygulamaları okul ve çevredeki işverenlerin iş birliği kurmasını sağlar. Staj uygulamaları okulun çevredeki iş olanakları hakkında bilgi sahibi olmasına ve ileriki yerleştirme süreçleri için deneyim elde etmesine katkıda bulunur. Staj uygulamasında gelişimsel yetersizliği olan birey eğitim aldığı alanı yansıtan bir iş yerine yerleştirilir. Gelişimsel yetersizliği olan birey burada sürekli olarak gözlenir ve değerlendirilir. Gelişimsel yetersizliği olan bireylerin bu süreçte kişilerarası becerilerini ve istihdam edilebilirlik becerilerini geliştirmesi en önemli amaçtır. Gelişimsel yetersizliği olan bireyler bu süreçte staj yaptıkları iş yerinin kültürüne ve çalışma koşullarına olabildiğince uyum gösterirler. Staj uygulamasından elde edilen değerlendirme verileri ışığında bireyin BEP'inde güncellemeler yapılabilir (Benz, Lindstrom ve Latta, 1999). Çıraklık eğitimi, deneyimsiz bir çalışanın alanında deneyimi olan bir "usta" ile eşleştirilmesi yoluyla iş becerilerinin geliştirilmesini kapsamaktadır. Çıraklık eğitiminde en temel amaç bireyin iş becerilerine yönelik yeterliklerinin geliştirilmesidir.

Kariyer hazırlığı çalışmaları kapsamında gerçekleştirilen mesleki deneyim etkinlikleri sırasında gelişimsel yetersizli-ği olan bireyin durumu sürekli olarak gözlenmeli ve işlevde bulunma düzeyi takip edilmelidir. Bireyin gereksinimlerine göre okulda destekleyici hizmetler sunulmalıdır. Nitelikli şekilde gerçekleştirilen kariyer hazırlığı uygulamaları gelişimsel yetersizliği olan bireyin okul sonrası dönemde yaşayacağı deneyimlerin farkında olmasını ve okulda gerçekleştirilen etkinlikleri anlamlandırmasını sağlamaktadır. Kariyer hazırlığı çalışmaları, gelişimsel yetersizliği olan bireye yönelik gerçekleştirilen kariyer farkındalığı ve kariyer keşfi çalışmalarını anlamlı bir temele oturtmakta ve bu çalışmaları tamamlayıcı nitelik göstermektedir (Morninstar ve ClavennaDeane, 2018). Diğer yandan mesleki deneyimler yoluyla gelişimsel yetersizliği olan birey iş dünyasıyla etkileşime girerek toplumsal çevresini arttırmaktadır. Bu durumun bireyin okul sonrası dönemde işe girme şansını arttıracacağı söylenebilir (Carter ve diğ., 2012). Okul döneminde gelişimsel yetersizliği olan bireye yönelik gerçekleştirilen kariyer gelişimi çalışmaları yetişkinlik yaşamına geçişte önemli bir temel oluşturmaktadır. Birey okuldan mezun olmadan önce yetişkinliğe geçiş döneminde gereksinim duyduğu hizmetler belirlenmeli ve bireye hizmet sunacak kuruma/personele iletilmelidir. Diğer yandan okul dönemi boyunca öğretilen becerilere yönelik genelleme çalışmalarına önem verilmesi bireyin okul sonrası dönemde işlevde bulunma düzeyini arttırabilir (Nittrouer, Pickens ve Shogren, 2015).

|Kastamonu Eğitim Dergisi, 2020, Vol. 28, No. 5 | 


\section{Kariyerin özümsenmesi}

Kariyer gelişimi sürecinin son aşaması olan kariyerin özümsenmesi okul sonrası dönemi kapsamaktadır. Bu dö-nemde gelişimsel yetersizliği olan bireyi özelliklerine uygun bir işe yerleştirmek ve bu işte sürdürülebilir şekilde çalışma-sını sağlamak temel amaçtır. Bununla birlikte bireyin çalışma yaşamı dışında kalan serbest zamanlarında neler yapa-cağı, nerede barınacağı gibi konularda da gereksinim duyulan hizmetler planlanarak sunulmalıdır. Kariyerin özüm-senmesi sürecinde gelişimsel yetersizliği olan bireyler okul döneminde kendilerine sunulan hizmetlerin kapsamının dı-şında kalmaktadır. Bu nedenle bireyin yakın çevresi, işverenleri ve çalışma arkadaşları doğal destek kaynağı olarak görülmeli ve bu paydaşların bireye sunacağı desteklerin nitelikli olması için gerekli önlemler alınmalıdır. Çalışma ya-şamında gelişimsel yetersizliği olan bireyler için en önemli doğal destek kaynaklarından birinin tipik gelişen çalışma arkadaşları olduğu söylenebilir (Hagner, Dague ve Phillips, 2015; Wehman, 2013). Çalışma arkadaşları gelişimsel ye-tersizliği olan bireyin çalışma yaşamında sürdürülebilir şekilde yer alması için savunuculuk, eğitim ve yardım sunma gibi alanlarda destek sunmakta, bununla birlikte bireyin iş yeri dışındaki sosyal çevresi için de önemli bir kaynak oluş-turmaktadır. Ancak çalışma arkadaşları gelişimsel yetersizliği olan bireylerle iletişim kurma ve sürdürmede desteğe gereksinim duymaktadırlar (Artar, 2018). Bu nedenle gelişimsel yetersizliği olan bireyin işe yerleştirilmesi sürecinde potansiyel doğal destek kaynakları belirlenerek desteklenmesi oldukça önemlidir.

Yetersizliği olan bireylerin çalışma yaşamına katılımında farklı istihdam modelleri uygulanmaktadır. Korumalı iş yeri, destekli istihdam ve rekabetçi istihdam modeli olarak sınıflandırılabilecek bu modeller farklı düzeyde destekler ve çalışma koşullarına işaret etmektedir (Migliore, Mank, Grossi ve Rogan 2007; Sitlington, Neubert ve Clark, 2010). Geli-şimsel yetersizliği olan bireylerin işlevde bulunma düzeyi onların bilişsel özellikleri ve yetersizlikten etkilenme derecele-rine göre farklılık göstermektedir. Bu nedenle yetişkinlik döneminde gelişimsel yetersizliği olan bireyler için gerçekçi beklentiler oluşturulmalıdır. Örneğin sınırlı derecede işlevde bulunma düzeyine sahip kimi bireyler için korumalı iş yeri modeline göre sürdürülen bir çalışma yaşamı daha uygun olabilecekken işlevde bulunma düzeyi daha yüksek olan bireyler içinse destekli istihdam ve rekabetçi istihdam modelleri kapsamında tipik gelişen bireylerle birlikte çalışmak daha işlevsel olabilir (Novak ve Rogan, 2010).

\section{SONUÇ VE ÖNERILER}

Gelişimsel yetersizliği olan bireyler başarılı bir yetişkinlik yaşamı için erken dönemde başlayan ve tüm okul dö-nemini kapsayan nitelikli eğitim ve destek hizmetlere gereksinim duymaktadırlar. Bu hizmetlerin temelinde ise kariyer eğitimi yer almaktadır. Ancak kariyer eğitimiyle ilgili alanyazın dikkate alındığında Türkiye'de hem gelişimsel yeter-sizliği olan bireylere hizmet sunan personelin hem de ailelerin kariyer eğitimi konusunda yeterli düzeyde farkındalığa sahip olmadıkları söylenebilir. Bu durum, paydaşların yetişkinlik yaşamının sorumluluklarıyla çok geç yüzleşmelerine neden olmakta ve gereksinim duyulan hizmetlerin erken dönemde sunulmasına engel olmaktadır. Bu nedenle bireyin ailesine tanılama aşamasının ardından gelişimsel yetersizliği olan bireyin yetişkinlik yaşamı ve kariyer gelişimi çalışmaları hakkında bilgilendirme çalışmaları yapılması önerilebilir. Diğer yandan bu bireylere hizmet sunan per-sonele (örn., özel eğitim öğretmenleri, genel eğitim öğretmenler, rehber öğretmen vb.) kariyer değerlendirmesi yapma, bu değerlendirme sonucunda bireye sunulan okul temelli etkinlikler ve toplum temelli deneyimlerle bireyin kariyerini destekleme konusunda gerekli yeterlikler kazandırılmalıdır.

Gelişimsel yetersizliği olan bireylerin başarılı bir yetişkinlik yaşamına ulaşması onların sahip olduğu bağımsız yaşam becerileriyle yakından ilişkilidir. Bağımsız yaşam becerileri hem bireyin çalışma yaşamında sürdürülebilir şekilde yer almasını hem de toplumda eşit bir birey olarak yaşamasını sağlamaktadır. Ancak gelişimsel yetersizliği olan bireylere yönelik ABD'de hazırlanan özel eğitim programları incelendiğinde, bu programların bağımsız yaşam çıktılarını elde etmede yetersiz kaldığı görülmektedir (Bouck, 2012). Ülkemizde de gelişimsel yetersizliği olan bireylere yönelik eğitim programları incelendiğinde, bu programların ve içerdiği öğrenmeöğretme süreçlerinin bireyi bağımsız yaşama hazırlamada yeterli olmadığı söylenebilir. Bu nedenle gelişimsel yetersizliği olan bireylerin bağımsız bir yetişkinlik yaşamına ulaşabilmesi için onlara sunulan özel eğitim programlarında bağımsız yaşam becerilerinin temel alınması ve toplum temelli bir öğretim sürecinin benimsenmesi önerilebilir.

Başarılı bir kariyer gelişiminin temelinde gelişimsel yetersizliği olan bireyi tanımak yer almaktadır. Bireyin ilgi, tercihlerinin belirlenmesi ve yeterliklerinin ortaya konması onun yetişkinlik yaşamındaki yolunu çizmede oldukça önemlidir (Morningstar ve Clavenna-Deane, 2018). Ancak Türkiye'de gelişimsel yetersizliği olan bireylere yönelik kari-yer değerlendirmesi için formal araçların (örn., ölçek, envanter vb.) bulunmaması bu bireylere yönelik kariyer gelişimi ve yönlendirme çalışmalarının önünde bir engel oluşturmaktadır. Bu nedenle uluslararası alanyazında yer alan değer-lendirme araçlarının işlevini yerine getirecek araç geliştirme ve Türkçe'ye uyarlama çalışmalarının gerçekleştirilmesi oldukça önemlidir.

Başarılı bir kariyer gelişimi için gelişimsel yetersizliği olan bireylerin okul döneminde çalışma yaşamıyla bağlantı kurarak mesleki deneyim elde etmesi oldukça önemlidir. Mesleki deneyimler yoluyla gelişimsel yetersizliği olan birey-lerin yeterli olduğu ya da ilgi duyduğu meslek alanlarının belirlenmesi için fırsatlar elde edilebileceği söylenebilir. Bu nedenle gelişimsel yetersizliği olan bireylerin devam ettikleri okullarla iş dünyası arasında bağlantı kurulmasının kari-yer gelişimi sürecine katkı sağlayacağı söylenebilir. Dolayısıyla farklı sektörlerde faaliyet gösteren işverenlerin ya da çalışanların okullara davet edilerek gelişimsel yetersizliği olan bireylerle etkileşim kurması ya da gelişimsel yetersizliği olan bireylerin belli aralıklarla düzenlenen geziler yoluyla çalışma ortamlarını gözlemlemesi önerilebilir. 


\section{KAYNAKÇA}

Artar, T. M. (2018). Çalışma arkadaşlarının zihin yetersizliği olan bireylerin çalışma yaşamına ilişkin görüş ve önerileri. Yayımlanmamış Yüksek Lisans Tezi. Eskişehir: Anadolu Üniversitesi Eğitim Bilimleri Enstitüsü.

Association for Career and Technical Education (2006). Reinventing the American high school for the 21st Century. Alexandria, VA: Author.

Baer, R. M., \& Daviso, A. W. (2013). Independent living and community participation. İçinde R. W. Flexer, R. M. Baer, M. Luft, \& T. J. Simmons (Eds.), Transition planning for secondary students with disabilities (s. 306-328). Boston: Pearson.

Benz, M. R., Lindstrom, L., \& Yovanoff, P. (2000). Improving graduation and employment outcomes of students with disabilities: Predictive factors and student perspectives. Exceptional Children, 66(4), 509-529. doi: 10.1177/001440290006600405

Benz, M. R., Lindstrom, L., \& Latta, T. (1999). Improving collaboration between schools and vocational rehabilitation: The youth transition program model. Journal of Vocational Rehabilitation, 13(1), 55-63. doi: 1052-2263

Bouck, E. C. (2012). Secondary students with moderate/severe intellectual disability: Considerations of curriculum and post-school outcomes from the National Longitudinal Transition Study-2. Journal of Intellectual Disability Research, 56, 1175-1186. doi: 10.1111/j.1365-2788.2011.01517.x

Bouck, E. C., \& Joshi, G. S. (2016). Transition and students with mild intellectual disability: Findings from the National Longditudinal Transition Study-2. Career Development and Transition for Exceptional Individuals, 39, 154-163. doi: 10.1177/2165143414551408

Bradley, V. J., Bershadsky, J., Giordano, S., Hiersteiner, D., Kennedy-Lizotte, R., \& Butterworth, J. (2015). Employing people with intellectual and developmental disabilities: Current status and emerging best practices. İçinde AAIDD (Ed.), Way leads on to way: Paths to employment for people with intellectual disability (s. 3-30). Washington, DC: American Association on Intellectual and Developmental Disabilities.

Brolin, D. E. (1997). Life centered career education: A competency based approach (5th edition). Virginia, VA: The Council for Expectional Children.

Brown, I., Hatton, C., \& Emerson, E. (2013). Quality of life indicators for individuals with intellectual disabilities: Extending current practice. Intellectual and Developmental Disabilities, 51(5), 316-332. doi: 10.1352/1934-9556-51.5.316

Carter, E. W., Austin, D., \& Trainor, A. A. (2012). Factors associated with the early work experiences of adolescents with severe disabilities. Intellectual and Developmental Disabilities, 49(4), 233-247. doi: 10.1177/1044207311414680

Cooney, B. F. (2002). Exploring perspectives on transition of youth with disabilities: Voices of young adults, parents, and professionals. Mental Retardation, 40, 425-435. doi: 10.1352/0047-6765(2002)

Cooney, G., Jahoda, A., Gumley, A., \& Knott, F. (2006). Young people with intellectual disabilities attending mainst-ream and segregated schooling: Perceived stigma, social comparison and future aspirations. Journal of Intellectual Disability Research, 50, 432-444. doi: 10.1111/j.1365-2788.2006.00789.x

Davis, R. V., \& Lofquist, L. H. (1984). A Pyschological theory of work adjustment. Minneapolis, MN: University of Minnesota Press.

Doren, B., Lindstrom, L., Zane, C., \& Johnson, P. (2007). The role of program and alterable personel factors in postsc-hool employment outcomes. Career Development for Exceptional Individuals, 30(3), 171-183. doi: $10.1177 / 08857288070300030601$

Échevin, D. (2013). Employment and education discrimination against disabled people in Cape Verde. Applied Eco-nomics, 45(7), 857-875. doi: 10.1080/00036846.2011.613775

Ferrari, L., Nota, L., \& Soresi, S. (2005). Conceptions of work in Italian adults with intellectual disability. Journal of Career Development, 34, 438-364. doi: 10.1177/0894845308316295

Flexer, R. W., Baer, R. M., Luft, M., \& Simmons, T. J. (2013). Transition planning for secondary students with disabili-ties. Boston: Pearson.

Grigal, M., Hart, D., \& Migliore, A. (2011). Comparing the transition planning, postsecondary education and employ-ment outcomes of students with intellectual and other disabilities. Career Development for Exceptional Individuals, 34(1), 4-17. doi: $10.1177 / 0885728811399091$

Grigal, M., Migliore, A., \& Hart, D. (2014). A state comparison of vocational rehabilitation support of youth with intel-lectual disabilities' participation in postsecondary education. Journal of Vocational Rehabilitation, 40(3), 185-194. doi: 10.3233/JVR-140683

Hagner, C. D. (1992). The Social interactions and job supports of supported employees. İçinde J. Nisbet (Ed.). Natural supports in school, at work, and in the community for people with severe disabilities (s. 217-240). Baltimore: Broo-kes Publishing Co.

Hagner, D., Dague, B., \& Phillips, K. (2015). Including employees with disabilities in workplace cultures strategies and barriers. Rehabilitation Counseling Bulletin, 58(4), 195-202. doi: 10.1177/0034355214544750 
Hall, D. T., \& Mirvis, P. H. (1996). The new protean career: Psychological success and the path with a heart. İçinde D. T. Hall (Ed.) The career is dead: Long live the career (s. 15-45). San Francisco, CA: Jossey-Bass.

Hall, S. A. (2017). Community involvement of young adults with intellectual disabilities: Their experiences and pers-pectives on inclusion. Journal of Applied Research in Intellectual Disabilities, 30(5), 859-871. doi: 10.1111/jar.12276

Hanley-Maxwell, C., \& Collet-Klingenberg, L. (2012). Preparing students for employment. İçinde P. Wehman \& J. Kre-gel (Eds.), Functional curriculum for elementary and secondary students with special needs (s. 529-561). Austin, TX: Pro-ED.

Harcourt, M., Lam, H., \& Harcourt, S. (2005). Discriminatory practices in hiring: Institutional and rational economic perspectives. The International Journal of Human Resource Management, 16(11), 2113-2132. doi: 10.1080/09585190500315125

Holland, J. L. (1996). Exploring careers with a typology: What we have learned and some new directions. American Psychologist, 51(4), 397-406. doi: 10.1037/0003-066X.51.4.397

Kraemer, B. R., Mclntyre, L. L., \& Blancher, J. (2003). Quality of life for young adults with mental retardation during transition. Mental Retardation, 41(4), 250-262. doi: 10.1352/0047-6765(2003)

Leake, D., \& Black, R. S. (2005). Cultural and linguistic diversity: Implications for transition personnel (Essential Tools Monograph Series). Minneapolis, MN: National Center for Secondary Education and Transition.

Lindstrom, L., Benz, M., \& Doren, B. (2004). Expanding career options for young women with learning disabilities. Career Development for Exceptional Individuals, 27(1), 43-63. doi: 10.1177/088572880402700104

Luecking, R. (2009). The way to work: How to facilitate work experiences for youth in transition. Baltimore: Brookes Publishing Company.

MacIntyre, G. (2014). The potential for inclusion: Young people of social inclusion as they make the transition from childhood to adulthood. Journal of Youth Studies, 17, 857-871. doi: 10.1080/13676261.2013.878794

Marshall, S. K., Stainton, T., Wall, J. M., Zhu, M., Murray, J., Wu, S., .... Young, R. A. (2018). Transition to adulthood as a joint parentyouth project for young persons with intellectual and developmental disabilities. Intellectual and Developmental Disabilities, 56(4), 263-277. doi: 10.1352/1934-9556-56.5.263

Meaker, T. (2016). Transition to employment. İçinde R. L. Morgan \& T. Riesen (Eds.). Promoting succesful transition to adulthood (s. 152-177). New York: The Guilford Press.

Migliore, A., Mank, D., Grossi, T., \& Rogan, P. (2007). Integrated employment of sheltered workshops: Preferences of adults with intellectual disabilities, their families, and staff. Journal of Vocational Rehabilitation, 26, 5-19. doi: 1052-2263

Miller, R. J., Lombard, R. C., \& Corbey, S. A. (2007). Transition assessment: Planning transition and IEP development for youth with mild disabilities. Boston: Pearson Education, Allyn and Bacon.

Morgan, R. L., \& Riesen, T. (2016). Promoting succesful transition to Adulthood for student with disabilities. London: Guilford Press.

Morningstar, M., \& Clavenna-Deane, B. (2018). Your complete guide to transition planning and services. Baltimore: Paul H. Brookes Publishing Company.

Nittrouer, C. L., Pickens, J. L., \& Shogren, K. A. (2015). Employment supports that promote job attainment, main-tenance, and advancement for people with intellectual and developmental disabilites. İçinde AAIDD. Way leads on to way: Paths to employment for people with intellectual disability (s. 165-182).Washington, DC: American Association on Intellectual and Developmental Disabilities.

Novak, D., \& Rogan, P. (2010). Social integration in employment settings: Application of intergroup contact theory. Journal of Intellectual and Developmental Disabilities, 48, 31-51. doi: 10.1352/1934-9556-48.1.31

O'Connor, M. P. (2009). Service works! Promoting transition success for student with disabilities through participation in service learning. Teaching Exceptional Children, 41(6), 12-17.

Qian, X., Johnson, D. R., Smith, F. A., \& Papay, C. K. (2018). Predictors associated with paid employment status of community and technical college students with intellectual disability. Journal on Intellectual and Developmental Di-sabilities, 123(4), 329343. doi: 10.1352/1944-7558-123.4.329

Rabren, K., Dunn, C., \& Chambers, D. (2002). Predictors of post-high school employment among young adults with disabilities. Career Development for Exceptional Individuals, 25(1), 25-40. doi: 10.1177/088572880202500103

Repetto, J. B.,Webb, K. W., Neubert, D. A., \& Curran, C. (2006). The middle school experience: Succesful teaching and transition planning for diverse learners. Austin, TX: Pro-Ed.

Rogan, P., Grossi, T. A., \& Gajewski, R. (2002). Vocational and career assessment. İçinde C. L. Sax, \& C. A. Thoma (Eds.), Transition assessment: Wise practices for quality lives (s. 103-117). Baltimore, MD: Paul Brookes Publishing.

Savaşır, R. (1999). Türkiye ve Avrupa Birliği ülkelerinde KOBi’ler açısından istihdam politikaları. Ankara: Kamu İşletmeleri İşverenleri Sendikası. 
Savickas, M. L. (2011). Constructing careers: Actor, agent, and author. Journal of Employment Counseling, 48(4), 179-181. doi: 10.1002/j.2161-1920.2011.tb01109.x

Sevak, P., O’Neill, J., Houtenville, A., \& Brucker, D. (2018). State and local determinants of employment outcomes among individuals with disabilities. Journal of Disability Policy Studies, 29(2), 1-10. doi: 10.1177/1044207318782676

Sitlington, P. L., Neubert, D. A., Clark, G. M., \& Oliver, P. (2010). Transition education and services for students with disabilities. New Jersey: Merill Pearson.

Steere, D. E., Rose, E., \& Cavaiuolo, D. (2007). Growing up transition to adult life for students with disabilities. Boston, MA: Allyn and Bacon.

Szymanski, E. M., \& Hershenson, D. B. (2015). An ecological approach to vocational behavior and career development of people with disabilities. İçinde R. M. Parker, E. M. Szymanski \& J. B. Patterson (Eds.), Rehabilitation counseling: Basics and beyond (s. 225-280). Austin, TX: PRO-ED.

Thurlow, M., Cormier, D., \& Vang, M. (2009). Alternative routes to earning a standard high schol diploma. Exceptiona-lity, 12(3), 135-149. doi: 10.1080/09362830903028424

Türkiye İstatistik Kurumu. (2002). Türkiye özürlüler araştırması. T. C. Başbakanlık Devlet İstatistik Kurumu Başkanlığı. Ankara: Devlet İstatistik Enstitüsü Matbaası.

Wagner, M., Newman, L., Cameto, R., Garza, N., \& Levine, P. (2005). After high school: A first look at the postschool experiences of youth with disabilities. A report from the National Longitudinal Transition Study-2 (NLTS2). Menlo Park, CA: SRI International. (Erişim Tarihi: www.nlts2.org/reports/2005_04/nlts2_report_2005_04_complete.pdf, 9.8.2018).

Wandry, D., Wehmeyer, M. L., \& Glor-Scheib, S. (2013). Life centered education teacher's guide. Arlington, VA: Co-uncil for Exceptional Children.

Wehman, P. (2013). Life beyond the classroom: Transition strategies for young people with disabilities. Baltimore, MD: Brookes Publishing Company.

Wehman, P., \& Bricout, J. (2001). Supported employment: New directions for the new millennium. İçinde P. Wehman (Ed.) Supported employment in business: Expanding the capacity of workers with disabilities (s. 3-22). Illinois: Trai-ning Resource Network

Wehmeyer, M. L., \& Webb, D. R. (2012). An introduction to adolescent transition education. İçinde M. L. Wehmeyer \& K. W. Webb (Eds.), Handbook of adolescent transition education for youth with disabilities (s. 1-10). New York: Ro-utledge.

Weidenthal, C., \& Kochar-Bryant, C. (2007). An investigation of transition practices for middle school youth. Career Development for Exceptional Individuals, 30, 147-157. doi: 10.1177/08857288070300030401

Yost, E. B., \& Corbishley, M. A. (1987). Career counseling: A psychological approach. San Francisco, CA: Jossey-Bass. 